\title{
Variation and distribution of freshwater algae (Chlorophyta) of District Mardan, Khyber Pakhtunkhwa, Pakistan
}

\author{
Shakir Ullah ${ }^{1,2^{*}}$, Uzma Salam¹, Yaseen $\mathrm{Khan}^{3}$, Naeem $\mathrm{Akbar}^{2}$ and \\ Khushnood Ur Rehman ${ }^{2}$ \\ 1. Key Laboratory of Plant Ecology, Northeast Forestry University, Harbin, 150040-China \\ 2. Department of Botany Islamia College Peshawar-Pakistan \\ 3. Key Laboratory of Plant Nutrition and Agri-environment in Northwest China, Ministry of Agriculture, College \\ of Natural Resources and Environment, Northwest A\&F University, Yangling, Shanxi-China \\ *Corresponding author's email: shakirshamas321@gmail.com \\ Citation
}

Shakir Ullah, Uzma Salam, Yaseen Khan, Naeem Akbar and Khushnood Ur Rehman. Variation and distribution of freshwater algae (Chlorophyta) of District Mardan, Khyber Pakhtunkhwa, Pakistan. Pure and Applied Biology. Vol. 10, Issue 3, pp640-650. http://dx.doi.org/10.19045/bspab.2021.100066

\begin{tabular}{llll}
\hline \hline Received: 26/08/2020 & Revised: 29/10/2020 & Accepted: 10/11/2020 & Online First: 24/11/2020 \\
\hline \hline
\end{tabular}

\section{Abstract}

Freshwater algae (Chlorophyta) had been studied poorly in district Mardan, Pakistan, especially on the taxonomic basis. The taxonomic study was carried out during 2017-2018 to evaluate the seasonal variation and the distribution of freshwater algae, i.e., Chlorophyta in the different regions of the district Mardan, Pakistan. A total of 55 species belonging to 15 other genera were recorded from other localities of district Mardan. The most dominant genus was Spirogyra with 17 species (30.91\%), followed by Tetraedron, Cosmarium, Closterium with $5(9.09 \%)$ and 4 (7.3\%) species respectively. Moreover, Cladophora, Zygnema, Mougeotia, Oedogonium and Stigeoclonium were found with 3 species $(5.45 \%)$, while Chaetophora, Rhizoclonium and Microspora each with 2 species (3.64\%). Furthermore, Closteriopsis, Ulothrix, and Uronema were 1 species each (1.8\%). Among the studied regions, the Arabi Kallay stream showed the highest numbers of species followed by Umar Khan and Kalpani streams. In contrast, Baizai stream and Takht Bhai canal sites showed the lowest numbers of species. Besides, the fluctuation in temperature also varies the distribution of Chlorophyta species, i.e., in summer; the numbers of species were higher, while in winter the decreasing level of species was noticed. The optimum temperature in summer was $35-40^{\circ} \mathrm{C}$, while in winter ranged $22-27^{\circ} \mathrm{C}$. This study not only gives information about the Chlorophyta freshwater algae in district Mardan but also can provide a baseline in the algal distribution for future studies in district Mardan.

Keywords: Chlorophyta distribution; District Mardan; Freshwater Algae; Seasonal variation

\section{Introduction}

\section{Geographical history}

Mardan is the second-largest city after Peshawar in the Khyber Pakhtunkhwa province, Pakistan. The district lies Latitude $34012^{\prime} 7.02^{\prime \prime}$ North and Longitude $72^{\circ} 03^{\prime} 9.14 "$ East. The total area of the district is (1632) 2 kilometres, with a population of 1.46 million, according to the 1998 census [1]. Mardan district broadly divided into two parts, northeastern hilly area and southwestern plain. The district is bounded with Bunir and Sawabi on the northeast and north site covered by Malakand agency, while on west and south by Charsadda and Nowshera can be seen respectively (Fig. 1) [2]. Among the seasons, summer is scorching and the temperature reaches $43.5^{\circ} \mathrm{C}$.

Algae have been found an exciting collection for research work due to their intuitive nature and distribution worldwide, which may be due to their ability to exist in different environmental conditions [3]. 
Normally, algae are important for producing organic photosynthetic materials which provide bases for food webs of animals [4]. According to Mursaleen et al. [1], algae play an important role both in human life as in the establishing of the environment [10]. Nitrogen fixation is an essential phenomenon for fertile soil and water blooms, which is carried out by Cyanophyceans [5]. Similarly, Various other findings revealed that algae are a vital source for the production of biodiesel through the trans-esterification process, as well as nutrition for fishes [6,7]. Earlier studies have shown that algae playing an important role in aquatic food chains, material circulation, energy flow, and information transmission [8, 9]. Subsequently, the results of Ullah et al. [10] showed that algae are a good source of food and energy; among them, many unicellular species are of prime importance. To know the distribution of algae, some studies had been done on the freshwater algae in Punjab and Swat, Pakistan by Sher \& Hazrat and Jaffer et al. [11, 12] while, Zarina et al. [13] reported green algae from northern Pakistan.

Furthermore, Sarim et al. [14] reported 89 species of 31 genera of Chlorophyceae, Bacillariophyceae, Xanthophyceae, and Cyanophyceae in Charsadda (neighbour district of Mardan). Moreover, the biological and physiochemical variation of algae was established by Ali et al. [15] in a brackish water fish pond. To study the biodiversity of Chlorophycean, a detailed study was done by Reshmi et al. [16] in Wetlands of Satna and investigated 52 species belongs to 32 different genera, 7 orders and 18 families. Khan et al. [3] had been done a morphological and taxonomic study in district Mardan and reported 73 freshwater algal species belongs to 25 families and 34 genera. A detailed survey on the freshwater algae belong to Chlorophyta, Cyanophyta, Xanthophyta, Charophyta and Chrysophyta from district Peshawar had been done by Yaseen et al. [17] and reported 13 genera with of 51 species. Also, other researchers [7, 18-20] had a similar study on green algal flora of different areas of Pakistan. Recently, Dastgeer et al. [21] reported 14 species and 9 genera from Marala headworks Sialkot Pakistan. However, previous literature showed that not much work had been done on the green algal flora (Chlorophyta) in district Mardan and their adjoining areas. Therefore, the present study aimed to elucidate the real number of species and distribution as well as to provide some basic knowledge related to different genera of Chlorophyta for future studies to cover the speculative gaps in district Mardan, KP, Pakistan.

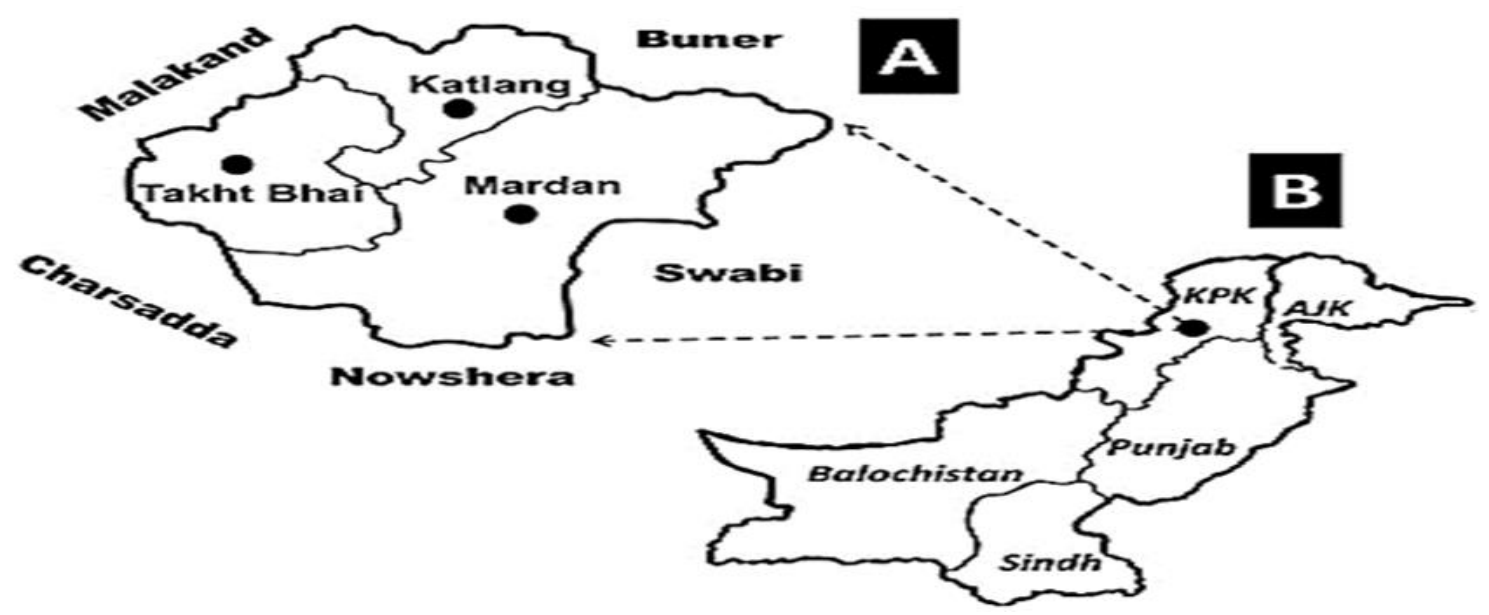

Figure 1. Topographical map of district Mardan Khyber Pakhtunkhwa Pakistan 


\section{Materials and Methods \\ Study area}

Mostly, the stream flows from north to south in district Mardan and drain into Kabul River [1]. Five research sites (Arabi kallay, Umar Khan, Kalpani, Baizai and
Takht Bhai canal) were selected for samplings (Fig. 2). Other important streams that join Kalpani are and Baghiari stream on the west and Muqam stream, coming from Sudham valley and Naranji stream from the Narrangi hills on the left.
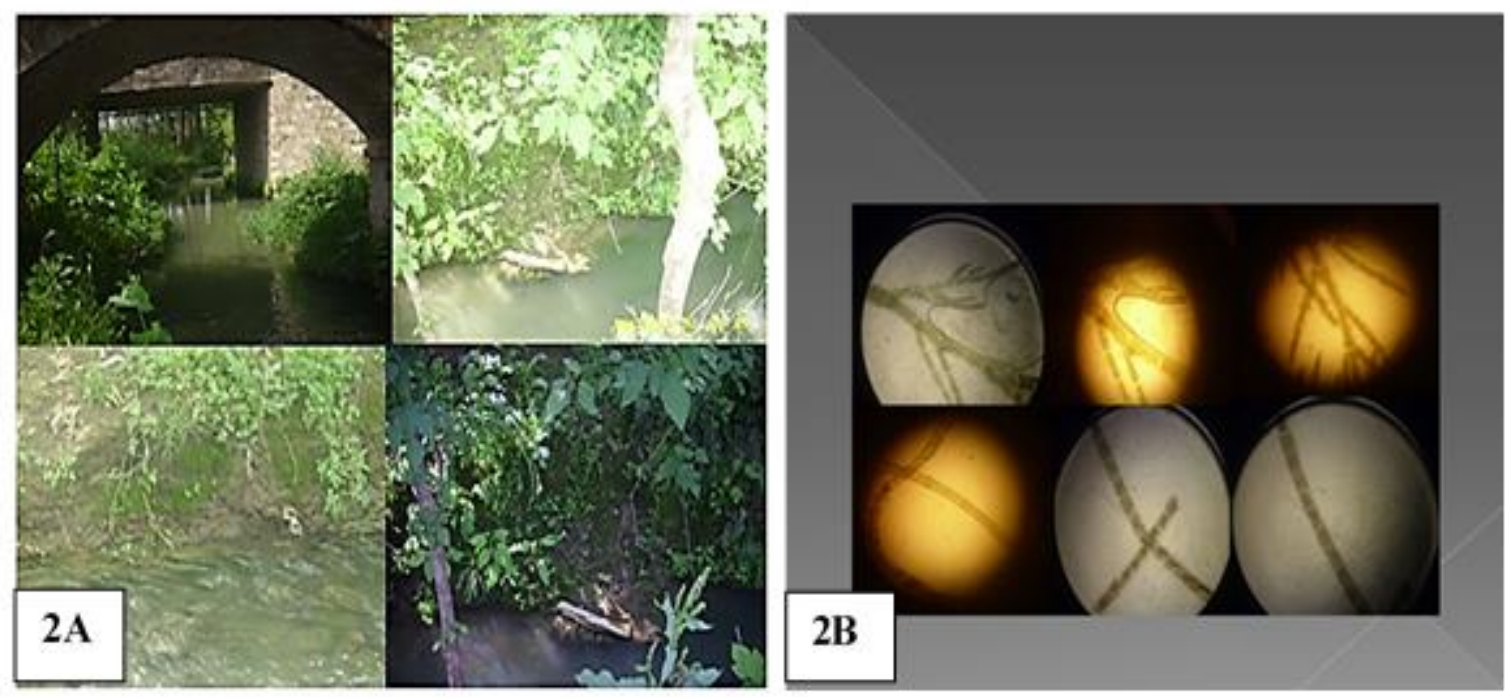

Figure 2. Sampling sites in Mardan and adjacent regions took in 2017-2018 (A), and some species observed with compound microscope (B)

\section{Samples collection}

More than 80 phytoplankton algal samples of freshwater algae were collected with the help of phytoplankton net, mesh size 5-10 $\mu \mathrm{M}$ from different regions of the district Mardan. The collection of samples was done in the mid of October 2017 to May 2018, following the method of Khan et al. [3]. Threadlike algae were taken together utilizing forceps, and desmid algae were gathered through pipette, large-sized algae and watered inside plants were hand-picked up from the congregation places. Some of the samples were collected from the top of the rocks near the aquatic builds, from shallow water, running water, standing waters, and canals through the knife, stick and polythene bags. The collected specimens were kept in the polythene bags and brought to the Laboratory, Department of Botany, Islamia College, Peshawar. The samples were preserved in $4 \%$ of Formalin solution in bottles.

\section{Laboratory work and identification}

The algal samples were treated according to [3] and used to guide for identification of $[22,23]$. From each sample, a single drop was taken through a pipette and put on the slide and then covered with a coverslip to observe their characteristics with a compound microscope. To find out the freshwater algal species, identification was made through the related literature [24-26].

\section{Results}

\section{Physiochemical properties of the water}

The study was conducted at the start of October 2017 in various regions of the Mardan district. During the investigation, different collections were done from other streams, where the physical characteristics were not the same. The collection of samples done from Umar Khan and Arabi kallay streams were almost the same because the temperature was similar in those areas $\left(28-30^{\circ} \mathrm{C}\right)$. In contrast, the temperature of the Takht Bhai canal was low compared to streams and the reason might be its rate of flow. Moreover, the 
depth of the streams was more than canal; therefore, more collections were done from streams compared to the canal. In spring and summer, the temperature was very high and ranged $30-35^{\circ} \mathrm{C}$. In later months, the temperature could be more than $400^{\circ} \mathrm{C}$, which can change the quality of the water. Furthermore, it was noticed that a high temperature could be increased salinity, which may be due to the slow flow of water in streams. Consequently, the quality of water could be disturbed and decreased the algal species.

\section{Quantification of genus and species}

In the current study, a total of 15 genera with 55 species of unicellular and filamentous algae were collected and identified from adjoining streams and canal of district Mardan. Among the studied genera, Spirogyra was the most abundant genus with 17 species (30.91\%). Furthermore, our results showed that Tetraedron and Cosmarium were five species, each (9.09\%) and Closterium with four species $(7.3 \%)$ in the samples. The other genera were Cladophora, Zygnema, Mougeotia, Oedogonium, and Stigeoclonium, with 3 species each $(5.45 \%)$ and Chaetophora, Rhizoclonium, and Microspora with 2 species each (3.64\%). In contrast, Closteriopsis, Ulothrix, and Uronema, with 1 species each $(1.8 \%)$ were recognized from the samples (Table 1).

Table 1. Numbers of genera with total no. of species and their percentage

\begin{tabular}{|c|c|c|c|}
\hline S. No. & Genus & No. of species & \% of species \\
\hline 1 & Chaetophora & 2 & 3.64 \\
\hline 2 & Cladophora & 3 & 5.45 \\
\hline 3 & Closteriopsis & 1 & 1.8 \\
\hline 4 & Closterium & 4 & 7.3 \\
\hline 5 & Microspora & 2 & 3.64 \\
\hline 6 & Mougeotia & 3 & 5.45 \\
\hline 7 & Cosmarium & 5 & 9.09 \\
\hline 8 & Oedogonium & 3 & 5.45 \\
\hline 9 & Rhizoclonium & 2 & 3.64 \\
\hline 10 & Tetraedron & 5 & 9.09 \\
\hline 11 & Spirogyra & 17 & 30.91 \\
\hline 12 & Stigeoclonium & 3 & 5.45 \\
\hline 13 & Ulothrix & 1 & 1.8 \\
\hline 14 & Uronema & 1 & 1.8 \\
\hline 15 & Zygnema & 3 & 5.45 \\
\hline
\end{tabular}

\section{Spirogyra}

Our study showed that Spirogyra was the most abundant genus with 17 species having filamentous and unbranched with no basal-distal differentiation (Table 2). The rhizoidal branches were developed laterally, where the filaments come in contact with the substrate. The cell was cylindrical, short to very lengthy in some species, with the plane or colligates end walls. Chloroplast was 1-16 straight or spirally arranged and parietal ribbon-like bodies were embedded in the cytoplasm.

Tetraedron, Cosmarium and Closterium Our findings revealed that Tetraedron and Cosmarium were the second largest group of genera after spirogyra comprising five species each (Table 3). Tetrahedron cells were solitary and unattached with various shapes. Moreover, it was observed that the cells were triangular and flat, pyramidal with poly-headric ends. The angles were variously lobed to form dichotomous or 
trichotomous spine-tipped progressions. The chloroplast was with too many parietal discs and tables. The genera of Cosmarium cells were variable in size, a little longer than wide and rarely twice as long as wide. Generally, the cells were flattened, symmetrical three planes at right angles to each other and restricted in the central to movable depths. Chromatophores usually axial in each cell, with four curved longitudinal tables and each cell contained 1-2 large pyrenoids. Cell walls were smooth, punctuate, granulate and varicose or papillate with the markings arranged in a definite pattern.

Table 2. Genus Spirogyra and their Species from Takht Bhai and adjacent regions of district Mardan

\begin{tabular}{|c|c|}
\hline Genus Spirogyra & Species \\
\hline 1 & S. Affinis \\
\hline 2 & S. Circumlineata \\
\hline 3 & S. Communis \\
\hline 4 & S. Condensate \\
\hline 5 & S. Conllinsii \\
\hline 6 & S. Crassa \\
\hline 7 & S. Daedaleoides \\
\hline 8 & S. Deciminia \\
\hline 9 & S. Denticulate \\
\hline 10 & S. Dubia \\
\hline 11 & S. Ellipsospora \\
\hline 12 & S. Fallax \\
\hline 13 & S. Farlowii \\
\hline 14 & S. Fluviatilis \\
\hline 15 & S. Formosa \\
\hline 16 & S. Fuellebornai \\
\hline 17 & S. Gratiana \\
\hline
\end{tabular}

Table 3. Distribution of algal genus and their species at district Mardan

\begin{tabular}{|c|c|c|c|}
\hline Genus & Species & Genus & Species \\
\hline Cladophora & C. Crispate & Closteriopsis & C. Longissima \\
\hline & C. Fracta & Ulothrix & U.cylindricum \\
\hline & C. Oligoclona & Uronema & U.elongatum \\
\hline Zygnema & Z.cyanosporum & Chaetophora & C.attenuata \\
\hline & Z.sterile & & C.pisiformis \\
\hline Mougeotia & M.capucina & Rhizoclonium & R.crassipelitum \\
\hline & M.genoflexa & & R.hookeri \\
\hline & M.punctata & & M.crassior \\
\hline Oedogonium & O.autumnale & Microspora & M.stagnorum \\
\hline & O.crassum & Tetraedron & T. Arthrodesmiforme \\
\hline & O.oblangum & & T.limneticum \\
\hline Stigeoclonium & S.attanautum & & T. Constrictum \\
\hline & S.flagelliferum & & T. Gracile \\
\hline & S.tenue & & T. Hastatumvar. Platinum \\
\hline Cosmarium & Cos.quinarium & Closterium & C. Littorale \\
\hline & Cos. Botrytis & & C. Acerosum \\
\hline & Cos. Subcostatum & & C. Parrulum \\
\hline & Cos.subcrenatum & & C. Leibleinil \\
\hline & Cos.triplicatum & & \\
\hline
\end{tabular}


Moreover, the cells of Closterium were elongated, usually attenuate and rarely straight. It was observed that most of the cells were curved and often strongly semilunar with no median compressions. The poles of the cells were truncate or attenuated to fine needle-like points. The cell wall was fine and smoothed, costate and striate. Additionally, the cell wall was colourless or yellow to brown. Chromatophores were thorough with a variable number of longitudinal ridges. Pyrenoids were few or many, usually in a single axial row or more rarely scattered throughout the chromosphere having terminal vacuole in the middle of cell ape.

\section{Cladophora, Zygnema, Mougeotia, Oedogonium and Stigeoclonium}

In the present study, it was noticed that the species of Cladophora genus were threadlike with the number of branches and were floating freely, while in some cases were attached firmly through rhizoidal cells. The cell was multinucleated and larger with thick walls. Moreover, a discoid shape single reticulate Chromatophore was observed. Several pyrenoids were present with quadric flagellate zoospores. Furthermore, our results demonstrated that Zygnema has vegetative cells with 18-22 $\mu \mathrm{M}$ in diameter, while some were ranged up to $270 \mu \mathrm{M}$ in diameter. The length of the cell was 50-90 $\mu \mathrm{M}$ without a flattened shape. The formation of Zygospores was in the tube. Genus Mougeotia contains several species with simple filament having one or two cell branches with cylindrical cells. The structure of Chromatophores was flattened with some pyrenoids in a single row. Also, it was noticed that the zygote was formed in the mating tubes having various structures and colours with exterior ornamented walls. Likewise, the findings of genus Oedogonium species revealed un-branched attached filaments. The shapes of cells were cylindrical and became enlarged towards the lower side, where one or more ring-like structures were resulting from the cell division. The green pigment of chloroplast was parietal with several pyrenoids. The nucleus was present at the periphery of the protoplast. The male cells antheridia were either small or in a compartment like cells and bearing antherozoids. The species of genus Stigeoclonium exhibited filaments without branches extended from the flat part of the thallus. The branches might be reduced to a mass of pseudoparenchymatous cells. A small thin film of mucilage covered the filament of the body. Several branches were protruding in random order composed of smaller cells than the central axis filament. The structure of chloroplast was of the parietal plate covering holding a large part of the cell wall and, most of the time, present in the cells of the branches. Cells contain one to several pyrenoids.

\section{Genus Chaetophora, Rhizoclonium, and Microspora}

Our findings revealed that the species of the genus Chaetophora were branched threadlike macroscopic structures with a tough outer layer, which could be round shape or irregular at apices. The filamentous body was multicellular with cylindrical or in protruded shape. Single Chromatophores was found covering the complete wall in new cells. Pyrenoid was available and, at later stages, become in the zonate form in larger compartments. The genus Rhizoclonium species were filamentous, making twisted free mats. However, some species were un-branched with short rhizoidal branches, while at some stages with long stems having more cells with no basal differentiation. The structure of cells was cylindrical, may be temporary or more extensive with somehow inflated walls. The discs of chloroplast were parietal with dense interpretation, while sometimes irregularly in a structure having an oval shape with pyrenoids. The filament of Microspora was un-branched in a detached form with slightly swollen cells. The cell wall of some species was thin, while in some it was lamellate and thick formed of two parts intermitting in the middle region. In mature stages, the filament showed some $\mathrm{H}$-shaped fragments at their points of 
contact and formed an irregular chloroplast.

The species of this genus indicated no pyrenoids.

\section{Genus Closteriopsis, Ulothrix and Uronema}

The genus Closteriopsis is phytoplankton green algae having larger chlorophytes with one cell curved at both sites. Our findings showed that the section contains several rings of pyrenoids in each chloroplast. The structure of the cell was slender, which has less pyrenoid, usually more bent. The cells were in separate form due to chloroplast. This species was abundant in ponds and streams compared to canals. The filamentous body of the genus Ulothrix species was un-branched with cylindrical cells, which might be coming outside from the holdfast with differentiation. The chloroplast was parietal and free-floating in some species and forming a ring throughout the cell at some stages. The genus is distinguished from another genus because the chloroplast covers the whole wall in this genus, more could be characterized by attached growth and containing the holdfast. The plants of genus Uronema could be compared with the early and developmental stages of Ulothrix and with the members of Chaetophoraceae, Stigeoclonium. This genus could be the second shape of Ulothrix because it also has the attached growth and holdfast at the basal body. The chloroplast was a crumpled parietal plate spreading for $2 / 3$ of the edge and $1 / 2$ to $2 / 3$ the length of the cells having two pyrenoids. The ending cells have no symmetry and tapering to a point with slightly covered.

\section{Variation and richness of the genus in different areas}

The most incredible variety of distribution was noticed among the species distribution in other regions. Our data demonstrated the high distribution proportion of Spirogyra in Arabi kallay and Baizai streams as well as Takht Bhai canals sites followed by Kalpani streams (Fig. 3). The lowest number of species, i.e., Closteriopsis, Ulothrix, and Uronema, was recorded from
Arabi kallay, Umar khan and Kalpani streams respectively (one each). Moreover, some of the species were found in uniform size distribution in Arabi kallay, Umar Khan, and Kalpani and Baizai streams. The variation in species distributions could be due to the physicochemical properties of the water, as well as the depth of the streams and canals.

Moreover, the temperature played an essential role in the distribution of the species in different localities. The high distribution and richness of species in canals and other few streams might be due to the optimum temperature of the region, which is considered an ideal place for the growth of green algae. Furthermore, our data showed that the Arabi kallay stream has the highest number of species, followed by Umar khan, Kalpani, Baizai streams, and Takht Bhai canals sites. The following increasing order of species was noticed among the streams.

\section{Discussion}

Algae are autotrophic organisms, constitute an essential group of Thallophyta. Generally, Chlorophyta or green algae is called chlorophytes belongs to the kingdom Protista, which is considered one of the most diverse groups of organisms. It is the group of green photosynthetic eukaryotic aquatic organisms, with typical features of plant-like chlorophyll, which given them green colour. Mostly chlorophytes species are in abundance in the water of lakes and oceans and rocks [27]. Green algae are also found in different symbiotic associations with other forms, including lichens, protozoa, and parasites on tropical plants. However, there are also found in the terrestrial environment, where they develop noticeable growth, which includes tree bark, rocks, walls of houses, and animal hairs [28]. There are estimated to be at least 600 genera with 10,000 species within the green algae. The present research work emphasizes green Algae of Takht Bhai and adjacent areas of district Mardan.

A total of 15 genera were identified with 55 species from different streams of Mardan, 
i.e., Arabi kallay, Umar Khan, Kalpani, Baizai streams and Takht Bhai canal site from October 2017 to May 2018. In the present study, thread shape form of species was found in an abundance of Chlorophyceae. Similar thread shape structure species were reported by Ali et al. [7] in the freshwater water of district Swat. Later on, it was noticed that the thallus shape structure was of genus spirogyra, with a more significant number of species compared to the other genera. The variation of species was found with area to area, and the dominant species observed were Spirogyra with 17 species $(30.91 \%)$ (Fig. 3). Moreover, our data showed that Spirogyra was holding a peak value of 4 in the group in all the study areas (Fig. 4). The Spirogyra was (100\%) prevailed and occupied all the designated habitations.

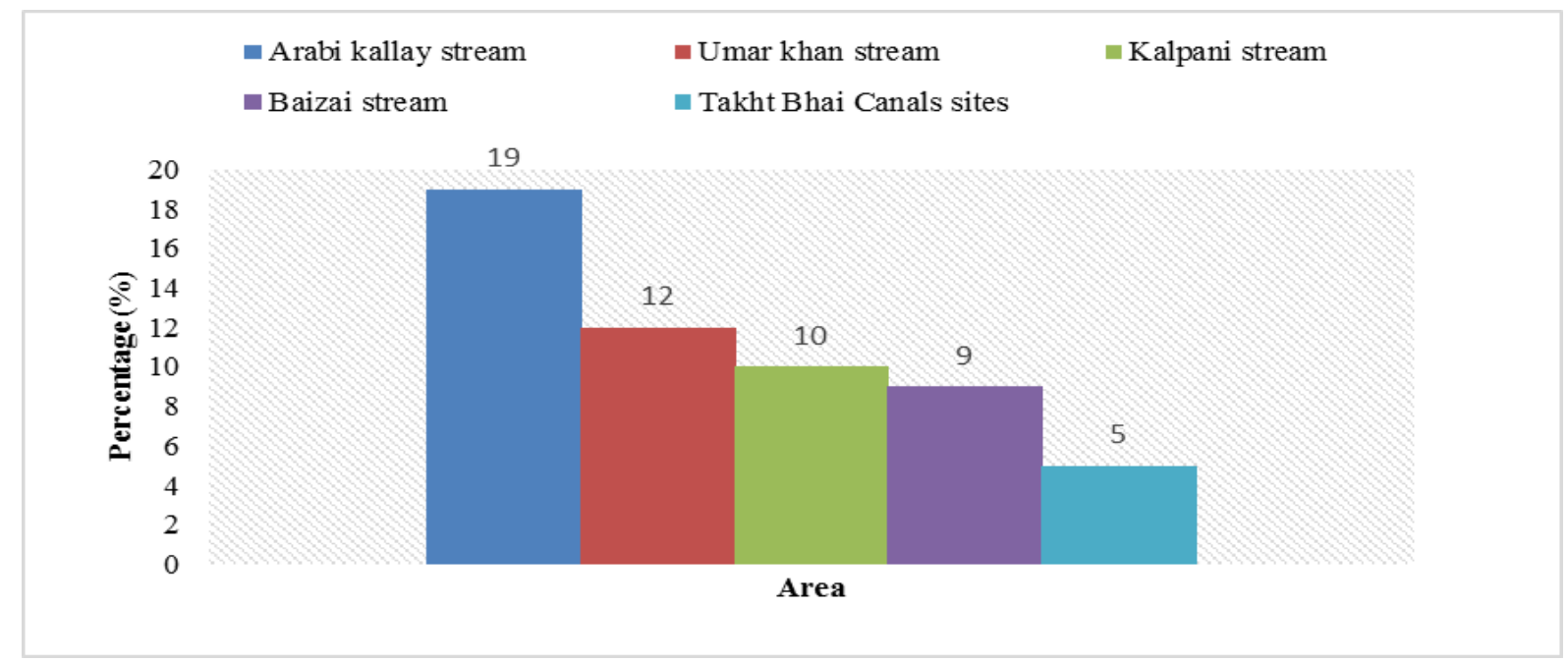

Figure 3. Total number of species occupied by different streams

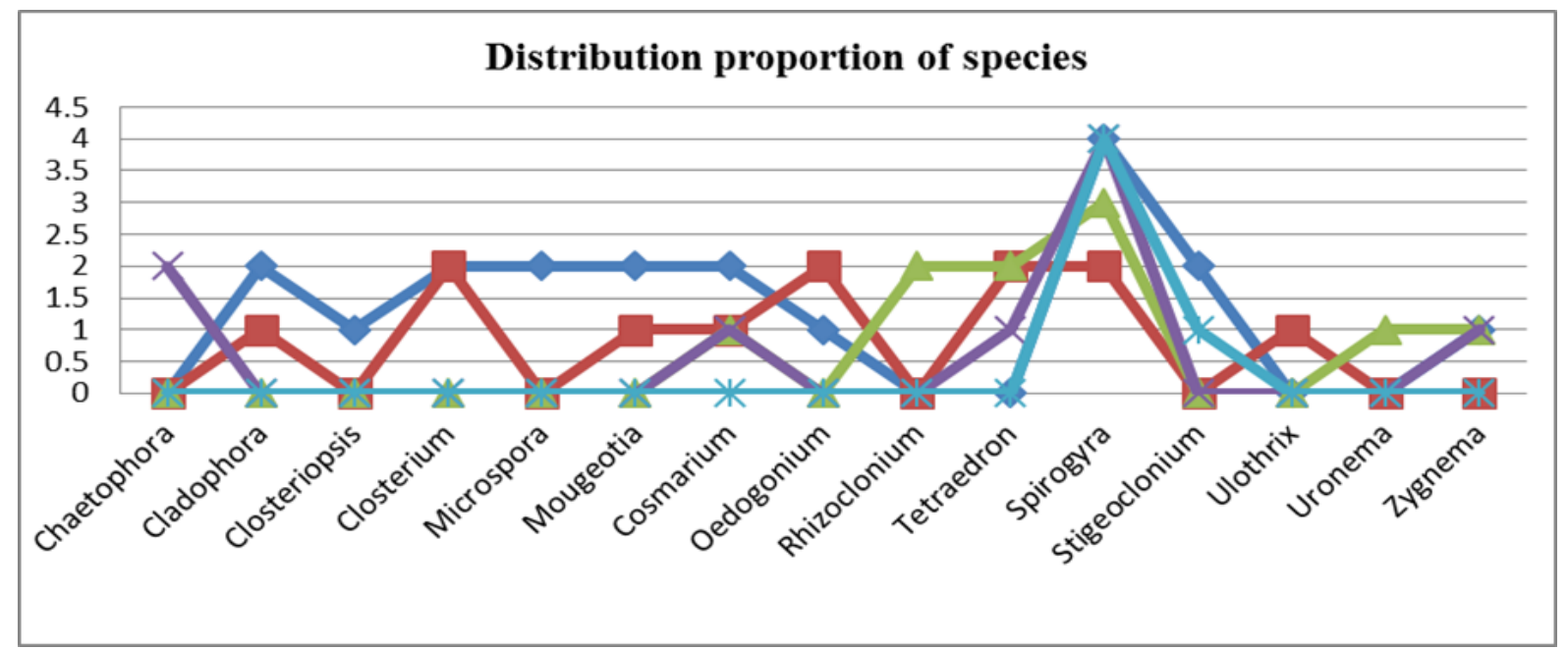

Figure 4. Distribution of species in different localities of district Mardan

Furthermore, Arabi kallay has the dominant number of species compared to other streams. The previous findings of Ali et al. [19] also indicated the highest reported species of Spirogyra. However, Tetraedron, Cosmarium and Closterium were abundant by species but not recorded from some sites, which display that these algae are not frequent as Spirogyra. Additionally, the genera Zygnema, Cladophora, Microspora, and Mougeotia were recorded more frequently than the Tetraedron, Cosmarium and Closterium in the collected samples. 
Additionally, it could be observed that Arabi kallay, Baizai stream and Takht Bhai canals have the highest number of spirogyra species compared to others. The fluctuation of species from low temperature to high temperature was also demonstrated by Krupa et al. [29], described that Zooplankton species of the measured regions of the sea were related in structure, while the alignment of the principal species was different. All of the observed species in our study were in planktonic form, which was similar to the findings reported by Aliya et al. [18] from Karachi Pakistan. In the present study, different green algal flora was observed with several concentrations from the stream, ponds and canals sites of Mardan. On the morphological bases the species were strapped unicellular, coccoids, branched or un-branched filaments, to multinucleated macrophytes and taxa with parenchymatic tissues. Our results demonstrated that there were regular variations in the growth and abundance of green algae. The increase of algae was noticed more in summer compared to winter, and it may be due to the optimum temperature in summer. Similar results were reported by Ali et al. [7], demonstrated that temperature plays an essential role in the distribution of phytoplankton flora.

Previously prescribed findings of Usinger et al. [30], showed that with the increasing temperature, the dissolved oxygen in water decreased. However, it could be observed that the variation of species and their distribution cause to affect the structural communities of the different streams and canals. According to the findings of Krupa et al. [29], the reason for this variation might be due to the organic pollution of the water. It was observed that the biomass of phytoplankton algae was in the range of $(0.23-0.29 \mathrm{~g} / \mathrm{m} 3)$ and $(0.65-0.66 \mathrm{~g} / \mathrm{m} 3)$ in the Middle Caspian and Northern Caspian respectively [29, 31]. Furthermore, seasonal variation in different species of green algal flora was also reported by Satpati et al. [32] in Indian Sundarbans mangrove forest and by Ali et al. [7] from swat Khyber Pakhtunkhwa Pakistan. The variation of species in different regions and their distribution could be due to the quality of the water [33]; however, comprehensive biological methods are needed to measure the quality of water [29]. Another factor that was noticed during the study was the depth of water, as more species were collected from stream compared to canals and ponds because the depth of the stream was more than ponds and canals, where more algal communities we noticed. However, in winter, the depth of water can change the quality of the water and harmful for algal communities because of eutrophication developments, which could change the nutritional quality of the water and reduced the algae. However, a positive relationship could be observed in summer [34].

\section{Conclusion}

Freshwater algae distribution was found to have fluctuated with temperature, and the highest numbers of species were reported in the summer season. In winter, the species were decreased because the temperature was low and more algal communities were affected. However, the deep level of water was off most important because a more significant amount of species was recorded as a stream has deep water. While in deep winter, water was affected by the low temperature and eutrophication, where the quality of the water changed. In the present work, Spirogyra was in abundance in the water compared to the other species. Moreover, the highest numbers of Spirogyra were reported from Arabi kallay followed by Umar khan and Kalpani streams. The seasonal variation was noticed, and from low to high temperatures, the species were increased. Furthermore, from winter to summer, the quality of the water improved, while in winter, the quality of water becomes bad, which makes it unfit for drinking and recreation. More research work is recommended to find the seasonal variation and distribution of freshwater as 
well as low water algae in the region of district Mardan Pakistan.

\section{Authors' contributions}

Conceived the research: KU Rehman, Designed the experiments: S Ullah \& U Salam, Collected the samples and performed the experiments: S Ullah \& N Akbar, Wrote the original draft: S Ullah \& $Y$ Khan, Reviewed and edited the manuscript: S Ullah \& Y Khan.

\section{Acknowledgements}

The authors are thankful to the Department of Botany, Islamia College Peshawar, for providing research facilities and an excellent research environment.

\section{References}

1. Mursaleen SS, Ali L, Ahmad N, Kuram I \& Barinova SS (2018). Algal communities of the Mardan River in ecological assessment of water quality in district Mardan, Pakistan. E Env Sci (3): 2.

2. Tufail M, Rehman AU \& Malik S (2017). Determinants of consanguinity and inbreeding coefficient in the multiethnic population of Mardan, Khyber Pakhtunkhwa, Pakistan. Asian Biomed 11(6): 451-60.

3. Khan M, Hussain F \& Musharaf $S$ (2016). A fraction of freshwater algae of Kalpani stream and adjoining area of district Mardan, Pakistan. Int J Biosci 1(3): 45-50.

4. Valeem EE \& Shameel M (2014). Fatty acid composition in different types of green algae from Sindh Pakistan. Int. $J$ P. Phychem 5(1): 71-6.

5. Paerl HW, Fulton RS, Moisander PH \& Dyble J (2010). Harmful freshwater algal blooms, with an emphasis on cyanobacteria. Sci World J 1: 76-113.

6. Ahmad F, Khan AU \& Yasar A (2013). Transesterification of oil extracted from different species of algae for biodiesel production. Afr J Environ Sci Technol 7(6): 358-64.

7. Ali A, Shinwari ZK \& Sarim FM (2010). Contribution to the algal flora (Chlorophyta) of fresh waters of district Swat. NWFP, Pakistan. Pak J Bot 42(5): 3457-62.

8. Jia J, Gao Y, Song X, Chen S (2019). Characteristics of phytoplankton community and water net primary productivity response to the nutrient status of the Poyang Lake and Gan River, China. Ecohydrol 12(7): 2136.

9. Linlin, C., Z. Guangwei, and L. Xiangyang, (2013). Characteristic of phytoplankton primary productivity and influencing factors in littoral zone of Lake Taihu. Acta Ecologica Sinica 33(22): 7250.

10. Ullah N, Sartaj M, Nawaz A, Hussain F, Shah M, Jang N, Jan F, Muhammad I, Ali K, Shuaib M, (2019). Diversity of fresh water algae from some important habitats of district Chitral, Pakistan. Pure and Appl Biol 8(3): 1943-1949.

11. Sher K \& Hazrat A (2012). Taxonomic study of green algae of lower river Swat KPK, Pakistan. Fuuast J Boil 2(1): 125-30.

12. Jaffer $M$, Ashraf $H$ \& Shaheen $S$ (2019). Morphoanatomical characterization of filamentous green algae of district Lahore based on classical and modern microscopic technique. Micr Res Tech 82(5): 580-5.

13. Zarina A, Shameel M \& Naz S (2010). Distribution of freshwater Blue-green algae (Cyanophyta) in northeastern Pakistan. Int J alga 12(3).

14. Sarim FM \& Zaman A (2005). Some freshwater algae of District Charsadda NWFP, Pakistan. Pesh Uni Teach Associ J 12: 5-10.

15. Ali M, Salam A, Iram S, Bokhari TZ \& Qureshi KA (2005). Studies on monthly variations in biological and physico-chemical parameters of brackish water fish pond, Muzaffargarh, Pakistan. J Res Sci 16(1): 27-38.

16. Reshmi S (2004). Chlorophycean biodiversity in Wet lands of Satna (MP) India. Biod. Env 171-90. 
17. Yaseen T, Ali M, Sarim FM, Rahim F, Wali S \& Ahmad I (2016). Fresh water Algae of district Peshawar, Khyber Pakhtunkhwa, Pakistan. Pure Appl Biol 5(4): 1.

18. Aliya R, Zarina A \& Shameel M (2009). Survey of freshwater algae from Karachi, Pakistan. Pak J Bot 41(2): 861-70.

19. Ali U, Begum I, Razzaq a, Rashid A, Hadi F \& Khan I (2016). Diversity and seasonal variations of fresh water algae in lund khwar, district mardan, khyber pakhtunkhwa pakistan. Pak. J Weed Sci 22(1).

20. Khuram I, Muhammad Z, Ahmad N, Ullah R \& Barinova S (2019). Green and charophyte algae in bioindication of water quality of the shah alam river (District Peshawar, Pakistan). Transylv Rev Syst Ecol Res 21(1): 1-6.

21. Dastgeer G, Hussain M, Aftab K, Tufail M, Malik M, Umar M, Sajid M (2020). Seasonal distribution of rotifer diversity in selected fish ponds and Marala Headworks Sialkot, Pakistan. $J$ Animal and Plant Sci 30(5): 12981308.

22. Tsalolikhin SJ (1995). Key to freshwater invertebrates of Russia and adjacent lands. St Petersburg 627.

23. Klymiuk V \& Barinova S (2016). Phytoplankton cell size in saline lakes. Res J Pharm Biol Chem Sci 7(1): 107785.

24. Prescott GW (1961). Algae of the western great lake area monograph. Michigan State University 1-975.

25. Tiffany LH \& Britton ME. The algae of Illinois. The University of Chicago Press.

26. Akhtar N \& Rehman SR (2009). Some members of ulotrichales from Jalala,
District Mardan, Pakistan. Pak J Pl Sci 15(1): 19-30.

27. Adl SM, Leander BS, Simpson AG, Archibald JM, Anderson OR, Bass D, Bowser SS, Brugerolle G, Farmer MA, Karpov S \& Kolisko M (2007). Diversity, nomenclature, and taxonomy of protists. Syst Biol 56(4): 684-9.

28. Barkatullah FH, Ali NI \& Ahmad IM (2013). Rock algae of Batkhela district Malakand, Pakistan. Pak J Bot 45(1): 329-40.

29. Krupa E (2019). Assessment of Changes in the Structure of Zooplankton Communities to Infer Water Quality of the Caspian Sea. Diversity 11(8): 122.

30. Usinger RL (1963). Aquatic insects of California: with keys to North American genera and California species. University of California Press.

31. Barinova S (2017). On the classification of water quality from an ecological point of view. Int J Environ Sci Nat Resour 2(2): 1-8.

32. Satpati GG, Barman N \& Pal R (2013). A study on green algal flora of Indian Sundarbans mangrove forest with special reference to morphotaxonomy. J Algal Biomass Utln 4(1): 26-41.

33. Moschonas G, Gowen RJ, Paterson RF, Mitchell E, Stewart BM, McNeill S, Glibert PM \& Davidson K (2017). Nitrogen dynamics and phytoplankton community structure: the role of organic nutrients. Biogeochem 134(12): 125-45.

34. Shabanova L, Khachaturov V \& Zlotov A (2010). The monitoring system of the Kazakhstan sector of Caspian Sea. InEGU General Ass Conf Abs 12: 3834 . 